\title{
Online Appendix \\ What Does Health Reform Mean for the Healthcare Industry? \\ Evidence from the Massachusetts Special Senate Election.
}

By MoHamad M. Al-Ississ and Nolan H. MilleR

\section{Appendix A: Extended Event Window and Post Period Analysis}

This Appendix contains tables supporting the analysis for the extended event window. Tables

A1 and A1a present results for the extended event window, January 14, 2010 - January 28, 2010. Tables A2 and A2a present results for the "post period” event window, January 21, 2010 March 23, 2010. 
TABLE A1: MAin Results For the EXTENDED Event Window ( JAN 14, 2010 - JAN. 28, 2010)

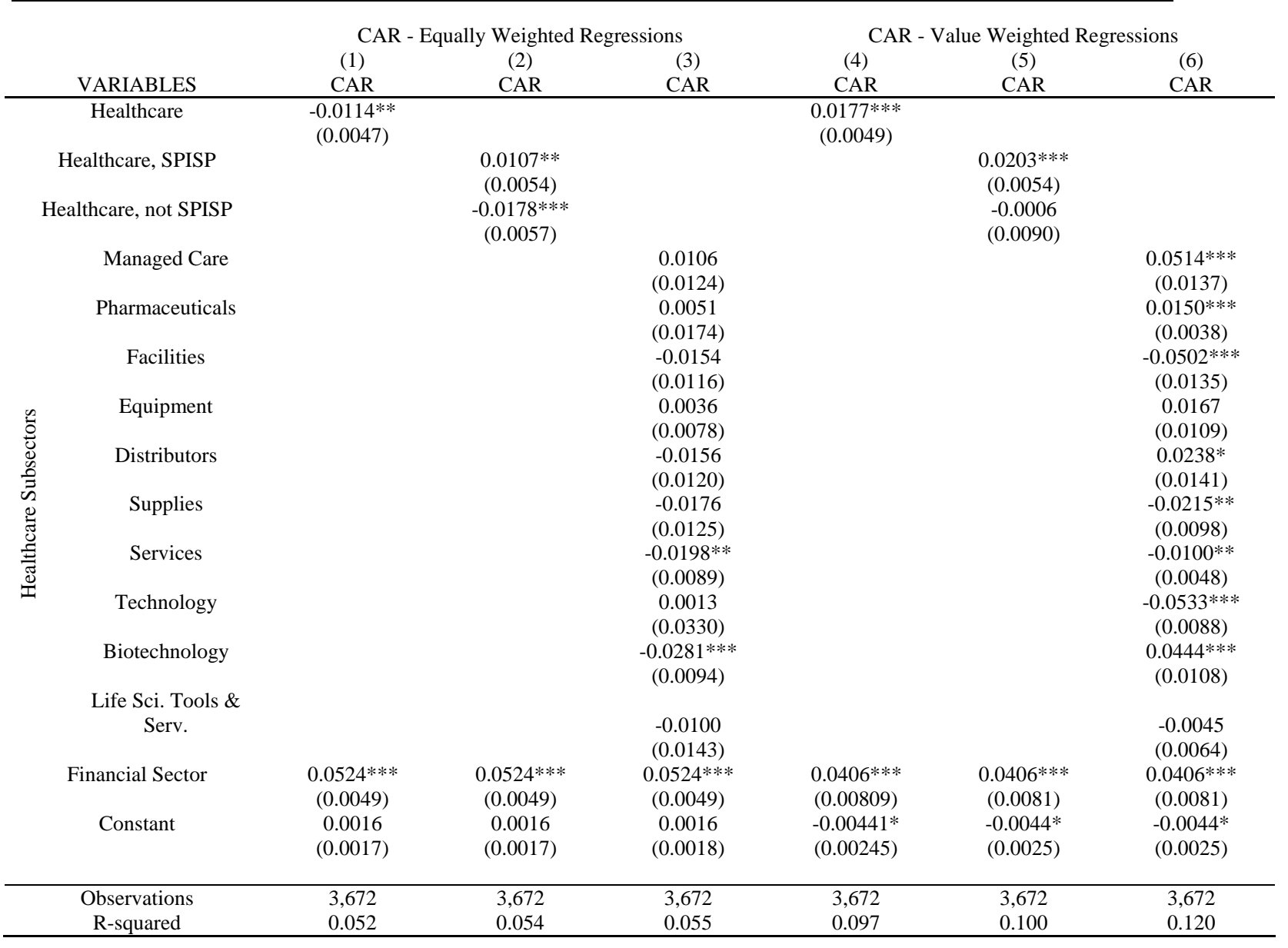

Notes: Columns $1-3$ each report estimates from equally weighted OLS regressions of the firms' CARs on the variables listed in the rows. Columns 4-6 each report estimates from OLS regressions weighted by the firms' market capitalization. Healthcare is an indicator variable for firms classified in two-digit GICS code 35, "Healthcare". Healthcare SPISP and Healthcare non-SPISP are indicator variables that further divide firms in to whether or not they are constituents of one of four S\&P Industry Select Portfolios (Health Care Equipment, Health Care Services, Pharmaceuticals, or Biotechnology). The variables labeled "Healthcare Subsectors" further divide all healthcare firms into subsectors based on seven digit GICS codes. Financial Sector is an indicator variable for whether the firm is in the financial sector. Robust standard errors in parentheses $\quad * * * \mathrm{p}<0.01,{ }^{* *} \mathrm{p}<0.05, * \mathrm{p}<0.1$. The number of observations is different from those in the original window due to the delisting of firms during this extended event window. 
Table A1a: Main Results for the Extended Event Window (Jan. 14, 2010 - Jan. 28, 2010, continued)

\begin{tabular}{|c|c|c|c|}
\hline & & $\begin{array}{c}\text { CAR - Equally Weighted } \\
\text { (1) }\end{array}$ & $\begin{array}{c}\text { CAR - Value Weighted } \\
\text { (2) }\end{array}$ \\
\hline \multirow{18}{*}{$\frac{\tilde{\omega}}{\omega}$} & Managed Care & $0.0421 * * *$ & $0.0583^{* * *}$ \\
\hline & & $(0.0127)$ & $(0.0136)$ \\
\hline & Pharmaceuticals & $0.0206^{*}$ & $0.0155^{* * * *}$ \\
\hline & & $(0.0108)$ & $(0.0038)$ \\
\hline & Facilities & $-0.0628 * * *$ & $-0.0708 * * *$ \\
\hline & & $(0.0144)$ & $(0.0142)$ \\
\hline & Equipment & $0.0218^{* *}$ & 0.0130 \\
\hline & & $(0.0098)$ & $(0.0119)$ \\
\hline & Distributors & 0.0132 & $0.0276^{*}$ \\
\hline & & $(0.0158)$ & $(0.0152)$ \\
\hline & Supplies & -0.0164 & -0.0172 \\
\hline & & $(0.0150)$ & $(0.0118)$ \\
\hline & Services & -0.0019 & $-0.0093^{*}$ \\
\hline & & $(0.0139)$ & $(0.0052)$ \\
\hline & Biotechnology & $0.0329 * * *$ & $0.0520^{* * *}$ \\
\hline & & $(0.0116)$ & $(0.0104)$ \\
\hline & Life Sci. Tools \& Serv. & $-0.0145^{*}$ & -0.0053 \\
\hline & & $(0.0082)$ & $(0.0071)$ \\
\hline \multirow{26}{*}{$\begin{array}{l}0 \\
\tilde{\omega} \\
\tilde{\omega} \\
1 \\
\tilde{0} \\
z\end{array}$} & Managed Care & -0.0066 & -0.0108 \\
\hline & & $(0.0155)$ & $(0.0153)$ \\
\hline & Pharmaceuticals & -0.0023 & -0.0047 \\
\hline & & $(0.0252)$ & $(0.0110)$ \\
\hline & Facilities & 0.0052 & $-6.21 e-05$ \\
\hline & & $(0.0132)$ & $(0.0117)$ \\
\hline & Equipment & -0.0016 & $0.0345^{* * *}$ \\
\hline & & $(0.0095)$ & $(0.0126)$ \\
\hline & Distributors & $-0.0336 * *$ & $-0.0143^{* *}$ \\
\hline & & $(0.0133)$ & $(0.0058)$ \\
\hline & Supplies & -0.0181 & $-0.0389 * * *$ \\
\hline & & $(0.0164)$ & $(0.0137)$ \\
\hline & Services & $-0.0267 * *$ & $-0.0160 *$ \\
\hline & & $(0.0108)$ & $(0.0096)$ \\
\hline & Technology & 0.00133 & $-0.0533 * * *$ \\
\hline & & $(0.0331)$ & $(0.0088)$ \\
\hline & Biotechnology & $-0.0402 * * *$ & -0.0055 \\
\hline & & $(0.0106)$ & $(0.0123)$ \\
\hline & Life Sci. Tools \& Serv. & -0.0096 & -0.0037 \\
\hline & & $(0.0158)$ & $(0.0098)$ \\
\hline & Financial Sector & $0.0524^{* * *}$ & $0.0406^{* * *}$ \\
\hline & & $(0.0049)$ & $(0.0081)$ \\
\hline & Constant & 0.0016 & $-0.0044 *$ \\
\hline & & $(0.0018)$ & $(0.0025)$ \\
\hline & Observations & 3,672 & 3,672 \\
\hline & R-squared & 0.059 & 0.127 \\
\hline
\end{tabular}

Notes: Column 1 reports estimates from equally weighted OLS regressions of the firms' CARs on the variables listed in the rows. Columns 2 reports estimates from OLS regressions weighted by the firms' market capitalization. The variables labeled "SPISP" are indicator variables that divide all healthcare firms into subsectors based on seven digit GICS codes and whether they are in one of four S\&P Industry Select Portfolios (Health Care Equipment, Health Care Services, Pharmaceuticals, or Biotechnology). The variables labeled Non-SPISP are indicator variables that divide firms based on subsector for firms that are not in one of the SPISP portfolios. Financial Sector is an indicator variable for whether the firm is in the financial sector. Robust standard errors in parentheses; ${ }^{* * *} \mathrm{p}<0.01,{ }^{* *} \mathrm{p}<0.05$, ${ }^{*} \mathrm{p}<0.1$. The number of observations is different from those in the original window due to the delisting of firms during this extended event window. 


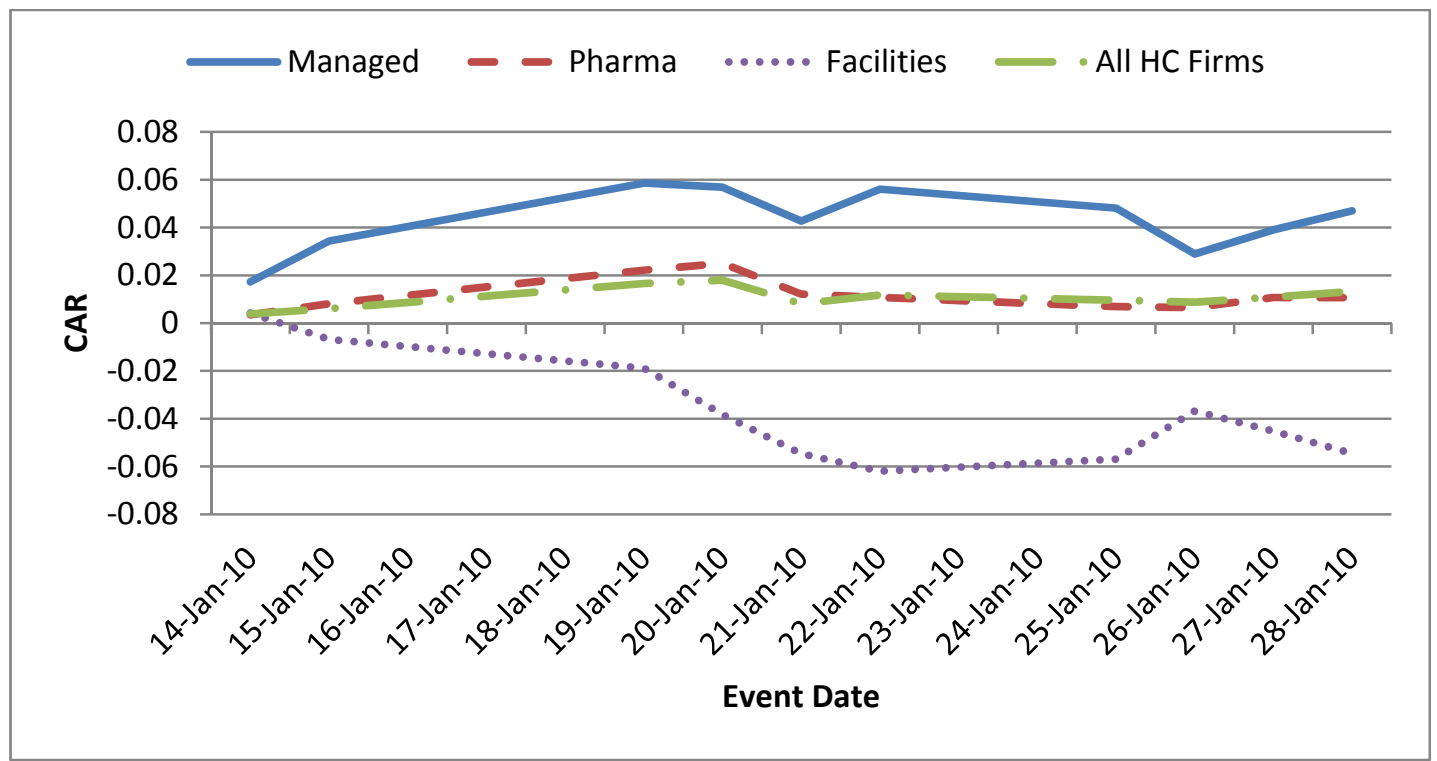

FIGURE A.1: CUMULATIVE ABNORMAL RETURN (WEIGHTED BY MARKET CAPITALIZATION) BY EVENT DAY FOR ALL HC FIRMS IN THE SPISP, AND FOR FIRMS IN THE FACILITIES, MANAGED CARE AND PHARMACEUTICALS SUBSECTORS.

Notes: Event window extending from Jan 14, 2010 till Jan 28, 2010, one day after President Obama’s State of the Union address. 


\begin{tabular}{|c|c|c|c|c|c|c|c|}
\hline & & \multicolumn{3}{|c|}{ CAR - Equally Weighted Regressions } & \multicolumn{3}{|c|}{ CAR - Value Weighted Regressions } \\
\hline & & (1) & (2) & (3) & (4) & (5) & (6) \\
\hline \multicolumn{2}{|c|}{ Healthcare } & -0.0020 & & & -0.0093 & & \\
\hline \multirow{2}{*}{\multicolumn{2}{|c|}{ Healthcare, SPISP }} & & 0.0184 & & & -0.0079 & \\
\hline & & & $(0.0142)$ & & & $(0.0170)$ & \\
\hline \multirow{2}{*}{\multicolumn{2}{|c|}{ Healthcare, not SPISP }} & & -0.0078 & & & $-0.0184^{*}$ & \\
\hline & & & $(0.0130)$ & & & $(0.0108)$ & \\
\hline \multirow{20}{*}{ 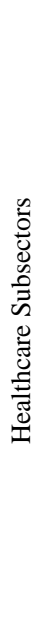 } & Managed Care & & & -0.0088 & & & $-0.0479 * * *$ \\
\hline & & & & $(0.0283)$ & & & $(0.0164)$ \\
\hline & Pharmaceuticals & & & 0.0138 & & & -0.0339 \\
\hline & & & & $(0.0459)$ & & & $(0.0302)$ \\
\hline & Facilities & & & $0.0603^{*}$ & & & $0.0448^{*}$ \\
\hline & & & & $(0.0319)$ & & & $(0.0229)$ \\
\hline & Equipment & & & -0.0063 & & & -0.0107 \\
\hline & & & & $(0.0146)$ & & & $(0.0178)$ \\
\hline & Distributors & & & -0.0006 & & & $0.0434 * * *$ \\
\hline & & & & $(0.0314)$ & & & $(0.0133)$ \\
\hline & Supplies & & & -0.0275 & & & $-0.0548 * * *$ \\
\hline & & & & $(0.0276)$ & & & $(0.0199)$ \\
\hline & Services & & & -0.0096 & & & 0.0212 \\
\hline & & & & $(0.0198)$ & & & $(0.0255)$ \\
\hline & Technology & & & -0.0246 & & & $-0.0458 * *$ \\
\hline & & & & $(0.0454)$ & & & $(0.0206)$ \\
\hline & Biotechnology & & & -0.0220 & & & $0.0269 * *$ \\
\hline & & & & $(0.0204)$ & & & $(0.0120)$ \\
\hline & Life Sci. Tools \& Serv. & & & 0.0420 & & & 0.0613 \\
\hline \multirow{3}{*}{\multicolumn{2}{|c|}{ Financial Sector }} & & & $(0.0355)$ & & & $(0.0444)$ \\
\hline & & $0.0157 * *$ & $0.0157 * *$ & $0.0157 * *$ & $-0.0271^{* * *}$ & $-0.0271 * * *$ & $-0.0271^{* * *}$ \\
\hline & & $(0.0074)$ & $(0.0074)$ & $(0.0074)$ & $(0.0098)$ & $(0.0098)$ & $(0.0098)$ \\
\hline \multirow{2}{*}{\multicolumn{2}{|c|}{ Constant }} & $0.0095 * *$ & $0.0095 * *$ & $0.0095 * *$ & $-8.84 \mathrm{e}-05$ & $-8.84 \mathrm{e}-05$ & $-8.84 \mathrm{e}-05$ \\
\hline & & $(0.0043)$ & $(0.0043)$ & $(0.0043)$ & $(0.0047)$ & $(0.0047)$ & $(0.0047)$ \\
\hline \multirow{2}{*}{\multicolumn{2}{|c|}{ Observations }} & 3,653 & 3,653 & 3,653 & 3,653 & 3,653 & 3,653 \\
\hline & & 0.001 & 0.002 & 0.003 & 0.013 & 0.013 & 0.029 \\
\hline
\end{tabular}

Notes: Columns $1-3$ each report estimates from equally weighted OLS regressions of the firms' CARs on the variables listed in the rows. Columns 4-6 each report estimates from OLS regressions weighted by the firms' market capitalization. Healthcare is an indicator variable for firms classified in two-digit GICS code 35, "Healthcare". Healthcare SPISP and Healthcare non-SPISP are indicator variables that further divide firms in to whether or not they are constituents of one of four S\&P Industry Select Portfolios (Health Care Equipment, Health Care Services, Pharmaceuticals, or Biotechnology). The variables labeled "Healthcare Subsectors" further divide all healthcare firms into subsectors based on seven digit GICS codes. Financial Sector is an indicator variable for whether the firm is in the financial sector. Robust standard errors in parentheses $\quad * * * \mathrm{p}<0.01,{ }^{* *} \mathrm{p}<0.05, * \mathrm{p}<0.1$. The number of observations is different from those in the original window due to the delisting of firms during this extended event window. 


\begin{tabular}{|c|c|c|c|}
\hline & & $\begin{array}{c}(1) \\
\text { CAR - Equally Weighted }\end{array}$ & $\begin{array}{c}(2) \\
\text { CAR - Value Weighted }\end{array}$ \\
\hline \multirow{17}{*}{$\frac{\tilde{\omega}}{\tilde{\omega}}$} & Managed Care & $\begin{array}{c}-0.0578^{* * *} \\
(0.0179)\end{array}$ & $\begin{array}{c}-0.0522 * * * \\
(0.0170)\end{array}$ \\
\hline & Pharmaceuticals & 0.0224 & -0.0330 \\
\hline & & $(0.0317)$ & $(0.0311)$ \\
\hline & Facilities & 0.0447 & $0.0672 * * *$ \\
\hline & & $(0.0284)$ & $(0.0236)$ \\
\hline & Equipment & 0.0101 & -0.0114 \\
\hline & & $(0.0231)$ & $(0.0211)$ \\
\hline & Distributors & $0.0255^{*}$ & $0.0434^{* * *}$ \\
\hline & & $(0.0152)$ & $(0.0144)$ \\
\hline & Supplies & -0.0327 & $-0.0469 * *$ \\
\hline & & $(0.0226)$ & $(0.0236)$ \\
\hline & Services & 0.0252 & 0.0269 \\
\hline & & $(0.0208)$ & $(0.0279)$ \\
\hline & Biotechnology & 0.0090 & $0.0370^{* * *}$ \\
\hline & & $(0.0382)$ & $(0.0111)$ \\
\hline & Life Sci. Tools \& Serv. & 0.221 & 0.117 \\
\hline & & $(0.153)$ & $(0.108)$ \\
\hline \multirow{26}{*}{ 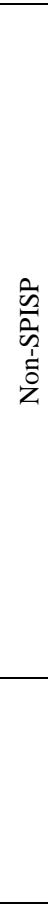 } & Managed Care & 0.0179 & -0.0090 \\
\hline & & $(0.0403)$ & $(0.0426)$ \\
\hline & Pharmaceuticals & 0.00965 & $-0.0693 * * *$ \\
\hline & & $(0.0660)$ & $(0.0262)$ \\
\hline & Facilities & 0.0671 & -0.0093 \\
\hline & & $(0.0439)$ & $(0.0375)$ \\
\hline & Equipment & -0.0109 & -0.0070 \\
\hline & & $(0.0172)$ & $(0.0173)$ \\
\hline & Distributors & -0.0170 & $0.0430 * *$ \\
\hline & & $(0.0490)$ & $(0.0197)$ \\
\hline & Supplies & -0.0254 & $-0.0869 * *$ \\
\hline & & $(0.0375)$ & $(0.0375)$ \\
\hline & Services & -0.0229 & -0.0297 \\
\hline & & $(0.0256)$ & $(0.0251)$ \\
\hline & Technology & -0.0246 & $-0.0458 * *$ \\
\hline & & $(0.0454)$ & $(0.0206)$ \\
\hline & Biotechnology & -0.0282 & -0.0395 \\
\hline & & $(0.0231)$ & $(0.0393)$ \\
\hline & Life Sci. Tools \& Serv. & 0.0232 & 0.0146 \\
\hline & & $(0.0345)$ & $(0.0120)$ \\
\hline & Financial Sector & $0.0157^{* *}$ & $-0.0271^{* * *}$ \\
\hline & & $(0.0074)$ & $(0.0098)$ \\
\hline & Constant & $0.0095^{* *}$ & $-8.84 \mathrm{e}-05$ \\
\hline & & $(0.0044)$ & $(0.0047)$ \\
\hline & Observations & 3,653 & 3,653 \\
\hline & R-squared & 0.005 & 0.033 \\
\hline
\end{tabular}

Note: Column 1 reports estimates from equally weighted OLS regressions of the firms' CARs on the variables listed in the rows. Columns 2 reports estimates from OLS regressions weighted by the firms' market capitalization. The variables labeled "SPISP" are indicator variables that divide all healthcare firms into subsectors based on seven digit GICS codes and whether they are in one of four S\&P Industry Select Portfolios (Health Care Equipment, Health Care Services, Pharmaceuticals, or Biotechnology). The variables labeled Non-SPISP are indicator variables that divide firms based on subsector for firms that are not in one of the SPISP portfolios. Financial Sector is an indicator variable for whether the firm is in the financial sector. Robust standard errors in parentheses; $* * * \mathrm{p}<0.01, * * \mathrm{p}<0.05$, ${ }^{*} \mathrm{p}<0.1$. The number of observations is different from those in the original window due to the delisting of firms during this extended event window. 


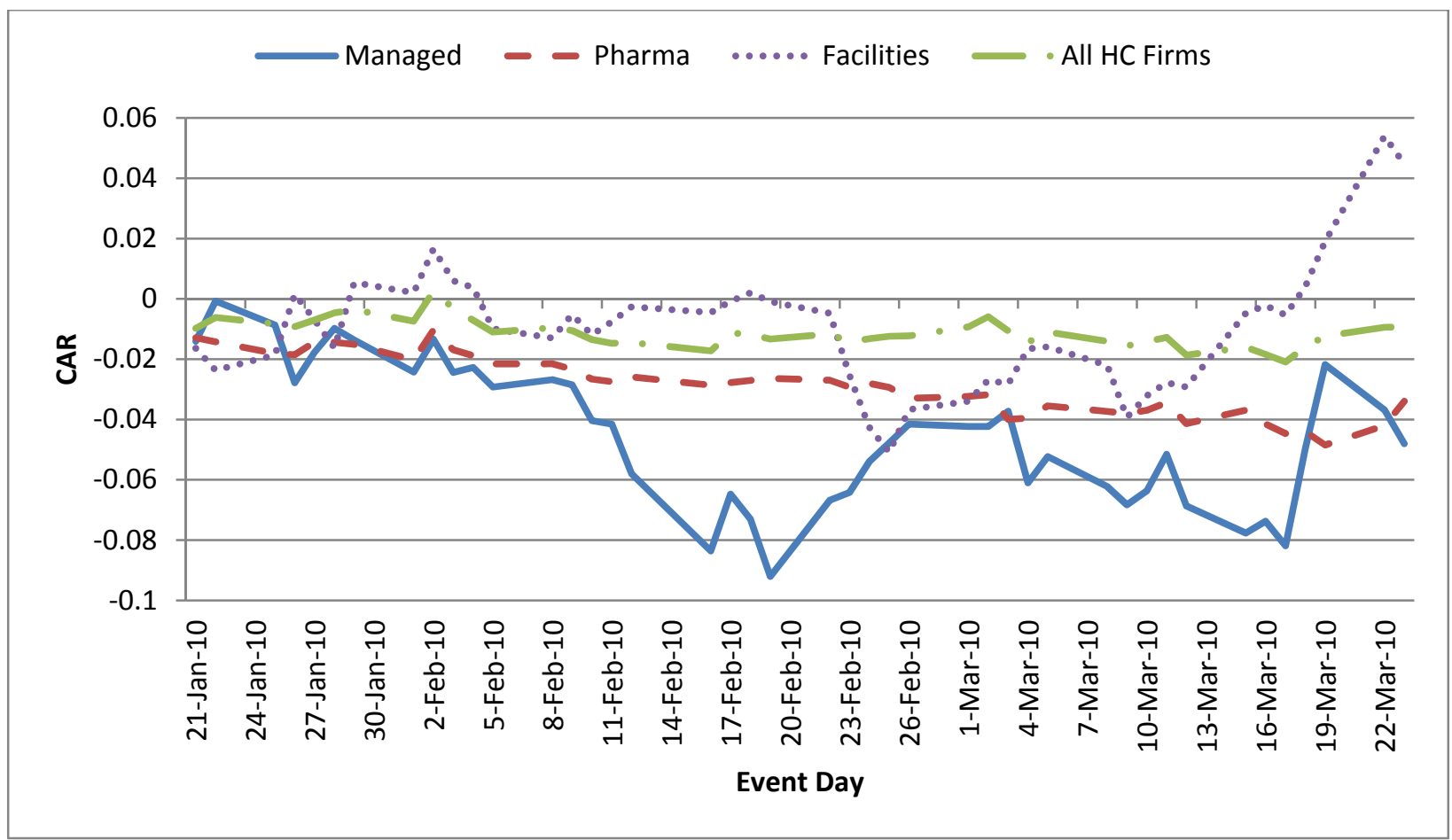

FigURE A.2: CUMULATIVE ABNORMAL RETURN (WEIGHTED BY MARKET CAPITALIZATION) BY EVENT DAY FOR ALL HC FIRMS IN THE SPISP, AND FOR FIRMS IN THE FACILITIES, MANAGED CARE AND PHARMACEUTICALS SUBSECTORS.

Notes: Event window extending from Jan 21, 2010 till March 23, 2010 when the Health Care law was signed into law. 


\section{Appendix B: Robustness to Controlling for Exposure to Other Potential Policy Changes}

In this Appendix we describe and present regression results in which we control for firms' exposure to other policy changes whose likelihood may have changed contemporaneously with Scott Brown's election. These policies include labor market reform, dividend tax reform, and financial market reform.

We control for exposure to labor reform and dividend tax reform by including unionization rates and dividend rates as controls in our event study regressions. The dividend data come from the CRSP database and include, for each firm, its 2009 dividend rate. Union membership data is based on the Current Population Survey as compiled in the Union Membership and Coverage Database from the CPS and include 2009 union membership rates for each firm based on its classification into one of 263 different CPS Industry Classification Codes. ${ }^{1}$

Exposure to financial sector reform is somewhat more complicated, as it is less obvious what cross-sectional variables might proxy for exposure to changes in financial-sector regulations. To address this, we re-run the three factor Fama-French model including as a fourth factor the return on a portfolio of financial-sector stocks minus the risk free rate of return according to equation (A1):

$$
R_{i t}-R_{f t}=\alpha_{i}+\beta_{i}\left(R_{m t}-R_{f t}\right)+\beta_{s i} \cdot S M B_{t}+\beta_{h i} \cdot H M L_{t}+\beta_{F I N i}\left(R_{F I N t}-R_{f t}\right)+\varepsilon_{i t} .
$$

where $R_{\text {FIN }}$ is the return on a portfolio of financial-sector stocks. The resulting coefficient on financial sector returns, $\beta_{F I N i}$, captures the partial correlation between a firm's return and financial sector returns. We then use the firm-level "financial-sector beta" coefficients as independent variables in our regressions aimed at capturing the relationship between the firm's abnormal returns and exposure to the financial sector. ${ }^{2}$

While controlling for the influence of these factors will help address the question of whether the impact of Scott Brown's election on healthcare stocks might have worked through channels other than Health Reform, it will obscure any effects of Health Reform that are correlated with the new control variables. For example, Health Reform included the "Cadillac

\footnotetext{
1 The dataset is compiled by Barry Hirsh and David Macpherson and available at www.unionstats.com.

2 Alternatively, we used the version of the Fama-French model including the performance of the financial-sector portfolio as a fourth factor to predict firms' abnormal returns net of exposure to the financial sector. Doing so has very little impact on the overall results.
} 
tax" on high-cost health plans, and such plans are often found in the benefit packages for union employees. Thus, even if the entire impact of the election worked through changes in the likelihood of Health Reform, we would expect that some of the effect would be correlated at the firm (or sector) level with unionization rates. While we will not be able to separately identify effects that work through changes in the likelihood of labor reform and changes that work through changes in the likelihood of health reform but are correlated with unionization, to the extent that our results are robust to including unionization and other controls we can conclude that the effect of the election was not solely due to changes in the likelihood of labor reform or other policies.

Tables A1 and A1a replicate the analysis in Tables 1 and 1a adding controls for the firm's 2009 dividend payout rate, (sector-level) unionization rate, and exposure to the financial sector as measured by the firm's "financial beta." Results are similar when we also include the square of each of these control variables. Due to the fact that $\beta_{F I N i}$ might be expected to behave differently for financial-sector firms, we exclude them from the regressions. The results for the impact of the election on healthcare stocks do not change substantially if they are included, although the coefficients on $\beta_{F I N i}$ do change.

Tables 5 and 5 a show that the main coefficients of interest change only slightly. We now find a 1.84 percent CAR to dollars invested in the healthcare sector, compared to 2.15 in the regressions without these controls. The returns to dollars invested in Managed Care, Equipment, Facilities and Pharmaceuticals remain statistically significant, with the magnitudes decreasing slightly.

Taking a closer look at the new controls, we find that unionization is significantly and negatively related to firms' CARs during the event window. As discussed above, this could be due to Brown's election leading the market to believe that labor reform was less likely to pass. Since one of the aims of labor reform was to make it easier for firms to unionize, we would expect the benefit of this to be felt most strongly by firms in industries with low unionization rates. Overall, healthcare firms had a mean unionization rate of 3.9 percent, slightly less than the overall rate of 6.7 percent, although as one might expect the hospital sector had a higher unionization rate of 8.8 percent. Thus, roughly speaking, the healthcare sector's lower unionization rate accounts for less than one tenth of one percentage point of the observed abnormal return to healthcare stocks compared to the market overall. 
The coefficient on firms' lagged dividend rate is insignificant in all specifications.

The coefficient on financial-betas are positive and significant in most specifications. However, the qualitative impact of financial-sector dependence is small, once again accounting for less than one tenth of one percentage point of the difference between returns to healthcare stocks and returns to the market overall. 
TABLE B1: ROBUSTNESS

\begin{tabular}{|c|c|c|c|c|c|c|c|}
\hline & & \multicolumn{3}{|c|}{ CAR - Equally Weighted } & \multicolumn{3}{|c|}{ CAR - Value Weighted } \\
\hline \multicolumn{2}{|c|}{ Healthcare } & $\begin{array}{c}0.00489 \\
(0.0032)\end{array}$ & & & $\begin{array}{c}0.0178 * * * \\
(0.00387)\end{array}$ & & \\
\hline \multicolumn{2}{|c|}{ Healthcare, SPISP } & & $\begin{array}{c}0.0111 * * * \\
(0.0041)\end{array}$ & & & $\begin{array}{c}0.0197 * * * \\
(0.0042)\end{array}$ & \\
\hline \multicolumn{2}{|c|}{ Healthcare, not SPISP } & & $\begin{array}{l}0.00310 \\
(0.0038)\end{array}$ & & & $\begin{array}{l}0.00540 \\
(0.0066)\end{array}$ & \\
\hline \multirow{10}{*}{ 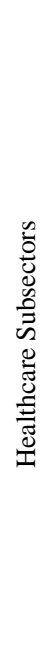 } & Managed Care & & & $\begin{array}{l}0.0239 * \\
(0.0124)\end{array}$ & & & $\begin{array}{c}0.0573^{* * *} \\
(0.0060)\end{array}$ \\
\hline & Pharmaceuticals & & & $\begin{array}{c}0.0118 \\
(0.0094)\end{array}$ & & & $\begin{array}{c}0.0245^{* * *} \\
(0.0076)\end{array}$ \\
\hline & Facilities & & & $\begin{array}{l}-0.00517 \\
(0.0091)\end{array}$ & & & $\begin{array}{c}-0.0353 * * * \\
(0.0121)\end{array}$ \\
\hline & Equipment & & & $\begin{array}{c}0.0156^{* *} \\
(0.0061)\end{array}$ & & & $\begin{array}{c}0.0161^{* * *} * \\
(0.0042)\end{array}$ \\
\hline & Distributors & & & $\begin{array}{l}0.00579 \\
(0.0104)\end{array}$ & & & $\begin{array}{c}0.0070 \\
(0.0051)\end{array}$ \\
\hline & Supplies & & & $\begin{array}{l}0.00657 \\
(0.0078)\end{array}$ & & & $\begin{array}{l}0.00565 \\
(0.0037)\end{array}$ \\
\hline & Services & & & $\begin{array}{l}0.00811 \\
(0.0070)\end{array}$ & & & $\begin{array}{l}0.00252 \\
(0.0052)\end{array}$ \\
\hline & Technology & & & $\begin{array}{c}0.0222 \\
(0.0221)\end{array}$ & & & $\begin{array}{l}-0.00624 \\
(0.0048)\end{array}$ \\
\hline & Biotechnology & & & $\begin{array}{l}-0.00820 \\
(0.0061)\end{array}$ & & & $\begin{array}{c}0.0141 * * * \\
(0.0037)\end{array}$ \\
\hline & $\begin{array}{l}\text { Life Sci. Tools \& } \\
\text { Serv. }\end{array}$ & & & $\begin{array}{c}0.0036 \\
(0.0106)\end{array}$ & & & $\begin{array}{l}-0.0142 \\
(0.0097)\end{array}$ \\
\hline \multicolumn{2}{|c|}{ Dividend } & $\begin{array}{c}-0.00881 \\
(0.0450)\end{array}$ & $\begin{array}{l}-0.0103 \\
(0.0444)\end{array}$ & $\begin{array}{l}-0.0135 \\
(0.0435)\end{array}$ & $\begin{array}{c}0.0513 \\
(0.0488)\end{array}$ & $\begin{array}{c}0.0431 \\
(0.0477)\end{array}$ & $\begin{array}{c}0.0360 \\
(0.0480)\end{array}$ \\
\hline \multicolumn{2}{|c|}{ Unionization } & $\begin{array}{c}-0.0002^{*} \\
(9.61 \mathrm{e}-05)\end{array}$ & $\begin{array}{l}-0.0002^{*} \\
(9.61 \mathrm{e}-05)\end{array}$ & $\begin{array}{c}-0.0002^{*} \\
(9.61 \mathrm{e}-05)\end{array}$ & $\begin{array}{c}-0.0003^{* * *} \\
(0.0001)\end{array}$ & $\begin{array}{c}-0.0003 * * * \\
(0.0001)\end{array}$ & $\begin{array}{c}-0.0003^{* * *} \\
(0.0001)\end{array}$ \\
\hline \multicolumn{2}{|c|}{ Financial Beta } & $\begin{array}{l}0.477 * \\
(0.257)\end{array}$ & $\begin{array}{l}0.462 * \\
(0.257)\end{array}$ & $\begin{array}{l}0.474^{*} \\
(0.257)\end{array}$ & $\begin{array}{c}0.378 \\
(0.261)\end{array}$ & $\begin{array}{c}0.369 \\
(0.261)\end{array}$ & $\begin{array}{c}0.308 \\
(0.260)\end{array}$ \\
\hline \multicolumn{2}{|c|}{ Constant } & $\begin{array}{l}0.00201 \\
(0.0017)\end{array}$ & $\begin{array}{l}0.00202 \\
(0.0017)\end{array}$ & $\begin{array}{l}0.00203 \\
(0.0017)\end{array}$ & $\begin{array}{l}-0.0004 \\
(0.0018)\end{array}$ & $\begin{array}{l}-0.0003 \\
(0.0018)\end{array}$ & $\begin{array}{l}-0.0003 \\
(0.0018)\end{array}$ \\
\hline \multicolumn{2}{|c|}{ Observations } & 2,845 & 2,845 & 2,845 & 2,845 & 2,845 & 2,845 \\
\hline \multicolumn{2}{|c|}{ R-squared } & 0.004 & 0.005 & 0.010 & 0.097 & 0.101 & 0.151 \\
\hline
\end{tabular}

Note: Columns 1 - 3 each report estimates from equally weighted OLS regressions of the firms' CARs on the variables listed in the rows.

Columns 4-6 each report estimates from OLS regressions weighted by the firms' market capitalization. Healthcare is an indicator variable for firms classified in two-digit GICS code 35, “Healthcare”. Healthcare SPISP and Healthcare non-SPISP are indicator variables that further divide firms in to whether or not they are constituents of one of four S\&P Industry Select Portfolios (Health Care Equipment, Health Care Services, Pharmaceuticals, or Biotechnology). The variables labeled "Healthcare Subsectors" further divide all healthcare firms into subsectors based on seven digit GICS codes. Dividend is the firm's 2009 dividend rate, Unionization is the 2009 proportion of the firm's workers who are union members (measures on a scale form 0 - 100), Financial Beta is the partial correlation between the firm's return and that of a portfolio of financial sector stocks. Financial Sector firms are not included in the regressions. Robust standard errors in parentheses. $\quad * * * \mathrm{p}<0.01$, $* * \mathrm{p}<0.05$, * $\mathrm{p}<0.1$. 


\begin{tabular}{|c|c|c|c|}
\hline & & $\begin{array}{c}\text { CAR - Equally Weighted } \\
\text { (1) }\end{array}$ & $\begin{array}{c}\text { CAR - Value Weighted } \\
(2)\end{array}$ \\
\hline \multirow{17}{*}{$\begin{array}{l}\tilde{n} \\
\tilde{n}\end{array}$} & Managed Care & $0.0636^{* * *}$ & $0.0632^{* * *}$ \\
\hline & & $\begin{array}{l}(0.00621) \\
0.0304 * * *\end{array}$ & $\begin{array}{l}(0.00550) \\
0.0249 * * *\end{array}$ \\
\hline & Pharmaceuticals & $\begin{array}{l}0.030426) \\
(0.00726)\end{array}$ & $\begin{array}{l}0.024997) \\
(0.00787)\end{array}$ \\
\hline & Facilities & $-0.0335 * *$ & $-0.0465 * * *$ \\
\hline & & $(0.0150)$ & $(0.0152)$ \\
\hline & Equipment & $0.0163^{* * *}$ & $0.0127 * * *$ \\
\hline & & $(0.00447)$ & $(0.00362)$ \\
\hline & Distributors & 0.00483 & 0.00775 \\
\hline & & $(0.00794)$ & $(0.00561)$ \\
\hline & Supplies & $0.00776^{*}$ & $0.00707^{*}$ \\
\hline & & $(0.00456)$ & $(0.00388)$ \\
\hline & Services & 0.00251 & 0.000621 \\
\hline & & $(0.0170)$ & $(0.00535)$ \\
\hline & Biotechnology & 0.00472 & $0.0147^{* * *}$ \\
\hline & & $(0.00752)$ & $(0.00382)$ \\
\hline & Life Sci. Tools \& Serv. & -0.00642 & 0.00196 \\
\hline & & $(0.00575)$ & $(0.00683)$ \\
\hline \multirow{30}{*}{ ڤ્ } & Managed Care & 0.00237 & 0.00362 \\
\hline & & $(0.0154)$ & $(0.0162)$ \\
\hline & Pharmaceuticals & 0.00300 & 0.00818 \\
\hline & & $(0.0132)$ & (0.00929) \\
\hline & Facilities & 0.00716 & -0.00832 \\
\hline & & $(0.0102)$ & $(0.00898)$ \\
\hline & Equipment & $0.0154 * *$ & $0.0317 * * *$ \\
\hline & & $(0.00765)$ & $(0.00614)$ \\
\hline & Distributors & 0.00654 & 0.000436 \\
\hline & & $(0.0161)$ & $(0.00700)$ \\
\hline & Supplies & 0.00616 & -0.000241 \\
\hline & & $(0.0107)$ & $(0.00881)$ \\
\hline & Services & 0.0103 & $0.0189 * *$ \\
\hline & & $(0.00707)$ & $(0.00771)$ \\
\hline & Technology & 0.0223 & -0.00625 \\
\hline & & $(0.0222)$ & $(0.00483)$ \\
\hline & Biotechnology & -0.0107 & 0.0104 \\
\hline & & $(0.00712)$ & $(0.00892)$ \\
\hline & Life Sci. Tools \& Serv. & 0.00472 & $-0.0277 * * *$ \\
\hline & & $(0.0117)$ & $(0.00910)$ \\
\hline & Dividend & -0.0160 & 0.0341 \\
\hline & & $(0.0429)$ & $(0.0483)$ \\
\hline & Unionization & $-0.000177 *$ & $-0.000274 * * *$ \\
\hline & & (9.61e-05) & $(0.000103)$ \\
\hline & Financial Beta & $0.455^{*}$ & 0.311 \\
\hline & & $(0.257)$ & $(0.261)$ \\
\hline & Constant & 0.00199 & -0.000260 \\
\hline & & $(0.00174)$ & $(0.00181)$ \\
\hline & Observations & 2,845 & 2,845 \\
\hline & R-squared & 0.014 & 0.162 \\
\hline
\end{tabular}

Notes: Columns 1 reports estimates from equally weighted OLS regressions of the firms' CARs on the variables listed in the rows. Columns 2 reports estimates from OLS regressions weighted by the firms' market capitalization. The variables labeled "SPISP" are indicator variables that divide all healthcare firms into subsectors based on seven digit GICS codes and whether they are in one of four S\&P Industry Select Portfolios (Health Care Equipment, Health Care Services, Pharmaceuticals, or Biotechnology). The variables labeled Non-SPISP are indicator variables that divide firms based on subsector for firms that are not in one of the SPISP portfolios. Dividend is the firm's 2009 dividend rate, Unionization is the 2009 proportion of the firm's workers who are union members (measures on a scale from 0 - 100), Financial Beta is the partial correlation between the firm's return and that of a portfolio of financial sector stocks. Financial firms are not included in the regressions. Robust standard errors in parentheses; ${ }^{* * *} \mathrm{p}<0.01,{ }^{* *} \mathrm{p}<0.05,{ }^{*} \mathrm{p}<0.1$. 